\title{
The Social-Institutional Bases of Gender Stratification: Japan as an Illustrative Case
}

\section{Citation}

Brinton, Mary C. 1988. The social-institutional bases of gender stratification: Japan as an illustrative case. American Journal of Sociology 94, no. 2: 300-334.

\section{Published Version}

http://dx.doi.org/10.1086/228993

\section{Permanent link}

http://nrs.harvard.edu/urn-3:HUL.InstRepos:3202907

\section{Terms of Use}

This article was downloaded from Harvard University's DASH repository, and is made available under the terms and conditions applicable to Other Posted Material, as set forth at http:// nrs.harvard.edu/urn-3:HUL.InstRepos:dash.current.terms-of-use\#LAA

\section{Share Your Story}

The Harvard community has made this article openly available.

Please share how this access benefits you. Submit a story.

Accessibility 


\title{
The Social-Institutional Bases of Gender Stratification: Japan as an Illustrative Case ${ }^{1}$
}

\author{
Mary C. Brinton \\ University of Chicago
}

\begin{abstract}
Gender stratification theory can be informed by a cross-cultural perspective and greater attention to the embeddedness of stratification processes within the social context. This article focuses on how the development and evaluation of human capital varies across cultural settings and on the implications this has for the degree of gender stratification in the economy. An argument is made for the theoretical utility of the concept of a human capital development system, constituted by the way social institutions-and social actors in those institutions - share the responsibilities of human capital development across the individual's life cycle. Japan is seen as having a system of human capital development that encourages the maintenance of greater gender stratification than the American system.
\end{abstract}

The institutional complexity of gender stratification has led to its examination with a number of different paradigms. Status-attainment theory, human capital theory, and sex-role socialization perspectives deal primarily with the formation and characteristics of labor supply; dual labormarket theory, theories of employer and employee discrimination, and some Marxist-feminist approaches deal primarily with the labor demand side. These perspectives represent entire sociological or economic literatures unto themselves, with varying emphases on the social actors they

\footnotetext{
${ }^{1}$ This research was supported in part by grant SES84-07208 from the National Science Foundation and by grants from the Japan Foundation and the Social Science Research Council. I would like to thank Gary Becker, Charles Bidwell, James Coleman, Tom DiPrete, Michael Hechter, Anthony Maier, and several anonymous reviewers who read and commented on an earlier draft of the paper. The paper also benefited from discussions with Toshio Yamagishi and from debate at the Comparative Education Workshop, the Family Studies Workshop, the Seminar on Rational Models in the Social Sciences, the Workshop on Class, Status, and Gender, and the Center for the Study of Industrial Societies, all at the University of Chicago, and the Sociology Department Colloquium Series at Northwestern University. Requests for reprints should be sent to Mary C. Brinton, Department of Sociology, 5848 S. University, Kelly 16, University of Chicago, Chicago, Illinois 60637.
}

(C) 1988 by The University of Chicago. All rights reserved. 0002-9602/89/9402-0004\$01.50 
consider to be ultimately important and the motivations they assume on the part of those actors. ${ }^{2}$

It has become increasingly clear that the most striking thing about the phenomenon of gender stratification is its systemic quality-it is supported by the major social and economic institutions of society, notably, the family, the educational system, and the work organization. The bases of occupational segregation by gender can be traced throughout the life cycle, commencing with the different socialization of sons and daughters (Maccoby and Jacklin 1974; Marini 1978; Stockard and Johnson 1980; Marini and Brinton 1984); continuing in the labor market through statistical discrimination, signaling and screening, and employer and employee perceptions and demands (Becker [1957] 1971; Phelps 1972; Arrow 1973; Spence 1973); and coming full circle to the adult, familial role demands that are hypothesized to lead to different patterns of labor-force participation for men and women (Mincer 1962; Hill 1978; Polachek 1979, 1981; Becker 1981). The interlocking system of social-institutional supports for gender stratification is powerful. Yet neither the macro-level interactions among social institutions nor the micro-level structure of human relationships have been adequately addressed by existing theories of gender stratification. $^{3}$

This article is based on two premises: (1) greater theoretical crossfertilization between sociology and economics will be helpful in overcoming theoretical inertia in the area of gender stratification, and (2) the incorporation of a cross-cultural perspective is crucial for the development of gender-stratification theory.

The first premise stems from the fact that current work in gender stratification shies away from viewing behavior as embedded in social structure. ${ }^{4}$ Existing theories are incomplete in that they fail to locate social actors within the social-institutional structure and within a web of social relationships, tending instead to see individuals as autonomous

${ }^{2}$ These theories have been extensively reviewed elsewhere (Brinton 1983; England 1983). England concludes that sex-role socialization, statistical discrimination, Marxism, institutional economics, and patriarchy disagree on "global issues" but are logically compatible in their explanations of segregation. She urges, "Research should be directed at discovering which of the processes reinforce each other and which are the most serious impediments to occupational desegregation" (1983, p. 42).

${ }^{3}$ Work that is consistent with this assertion includes that by Curtis (1986) and BenPorath (1980). Curtis attributes bias in stratification theory to a preoccupation with large-scale production organizations and with exclusively economic relationships, arguing that greater attention should be paid to exchange processes within units such as the family. In economics, Ben-Porath (1980) provides a transaction-costs account of intrafamilial relations.

${ }^{4}$ The problem of embeddedness of economic behavior in social life is discussed by Granovetter (1985). 
decision makers with a substantial degree of implicit control over their own fates in the labor market. The particular focus in this paper will be on the institutional elaboration of human capital theory, which is at once the most carefully specified theory in terms of its micro-level mechanisms and the most devoid of sociological content in terms of tying those mechanisms to the social context and theoretically incorporating the social context. I consider the role of the family, the educational system, and the work organization in producing gender stratification through their shaping of men's and women's human capital. Although I acknowledge that labor unions, state employment policy, and other macro-level actors and institutions may also be important in producing gender stratification in the economy, I focus in this work on the institutions through which all individuals move in the course of their life cycles-institutions that play critical roles in child and adult socialization and in the development and evaluation of human capital.

The second premise, the importance of cross-cultural research, is based on the observation that both the sociological and economic literatures are oriented toward the explanation of occupational or wage differences between men and women in American society and thus take for granted what may be rather specific features of American social institutions. Roos (1985) has argued for the potential contribution of comparative studies of occupational gender segregation. Collins (1986) singles out gender inequality as one of the most promising current theoretical "problems" in sociology, but one that begs for comparative historical analysis. Similarly, I argue here that a research tradition that concentrates almost exclusively on the explanation of differences in economic outcomes between individual men and women in one culture makes it difficult to develop a theory of gender stratification that confronts issues of microlevel interaction within the macro-level institutional setting. ${ }^{5}$

The paper is organized as follows. In the first section, I outline the requirements that must be fulfilled by a theory of gender stratificationrequirements to anchor or embed gender-stratification processes in the social context. I then develop the concept of a human capital development system in order to incorporate these requirements and argue that such systems differ across industrial societies depending on the way that the responsibility for human capital development is shared across the life cycle among social institutions and on the way that human relationships are structured within institutions. The article uses material from Japan, a

\footnotetext{
${ }^{5}$ See Coleman (1986) for a discussion of the bifurcation of American sociology into empirical work that takes the individual as the unit of analysis and theoretical work that focuses on macro-level structures.
} 
society with an arguably different social structure, pattern of social relationships, and degree of gender stratification from those of the United States, to illustrate how human capital development systems are linked to patterns of gender stratification. This comparison demonstrates the usefulness of following the two premises stated above: that economic and sociological concepts can be fruitfully combined into one model of gender stratification and that cross-cultural data can be used to inform such a model.

A note on the use of the term "gender stratification" is important here. Since a large portion of the male-female wage gap can be explained by occupational sex segregation (England 1981; Treiman and Hartmann 1981), empirical studies of gender stratification in the economy have increasingly focused on occupational segregation (Beller 1984; Rosenfeld 1984; Roos 1985) and on job segregation within occupations (Bielby and Baron 1986). Because of this strong, demonstrated relation between jobs and wages, I take occupational segregation, or, more broadly, differing positions in the labor market, as the dependent variable for genderstratification studies. This is not to deny, however, the importance of the sexual division of labor in other spheres with which this article does not deal, such as the household or the political realm.

\section{REQUIREMENTS FOR A THEORY OF GENDER STRATIFICATION}

The main requirements for a theory of gender stratification are:

1. Identification of the most important decision makers involved in processes of occupational selection and assignment. This specification is the most important and is the axis around which the following three specifications revolve.

2. Identification of the incentives for decision makers-What outcomes are being maximized, and why? What role do values, prejudices, and expected returns (economic, prestige, or other) play in structuring outcomes?

3. Informational inputs to decision making-To what information sources does each set of actors have access? With what degree of certainty can they trust this information? Specifically, How does the past relative success of men and women in the labor market determine the present opportunity structures of men and women as groups and how does it influence their human capital development? How does information on the relative human capital of men and women as groups influence decision makers (employers) on the demand side? This set of questions accentuates the need for a processual theory, or one that will predict how individuals with given ascriptive characteristics come to be matched with certain occupational slots. A major flaw in many stratification studies has been 
the exclusive emphasis on either the supply or the demand aspects of the problem rather than the interaction and systematic working out of the two together (Granovetter 1981). But only through theoretical exploration of this interaction can we arrive at a causal theory of gender stratification and, by extension, a theory that predicts persistence or change in genderstratification patterns over time.

4. Resources to which decision makers have access. These resources include the material resources of decision makers and access to institutional resources and prevailing ideology that will support their decisions.

In the next section, I propose a way of dealing with these issues by combining a social-institutional approach to gender stratification with concepts from human capital theory.

\section{HUMAN CAPITAL DEVELOPMENT: A SOCIAL-INSTITUTIONAL VIEW ACROSS THE LIFE CYCLE}

As stated by Blaug, "The concept of human capital, or 'hard core' of the human capital research program, is the idea that people spend on themselves in diverse ways, not for the sake of present enjoyments, but for the sake of future pecuniary and nonpecuniary returns" $(1976$, p. 829). He continues, "All these phenomena-health, education, job search, information retrieval, migration, and in-service training - may be viewed as investment rather than consumption, whether undertaken by individuals on their own behalf or undertaken by society on behalf of its members. What knits these phenomena together is not the question of who undertakes what, but rather the fact that the decision-maker, whoever he is, looks forward to the future for the justification of his present actions" (1976, p. 829; italics mine).

I argue that it is precisely the "question of who undertakes what" that is important in the application of a human capital framework to issues of inequality, in this case, gender inequality, and that this focus can be brought into a human capital framework through the explicit theoretical consideration of social institutions. When human capital theory deals with the issue of the distribution of human capital investment decisions and costs among social actors, the main distinction made is between actors on the labor supply side (the individual or the household as a whole) and the labor demand side (employers). This is well and good. Yet this division of labor or decision-making power is an institutional one, constituted by the way the family, the educational system, and the firm share the responsibilities and costs of training workers. This division of labor undoubtedly varies cross-culturally, and the division may affect the differential development of male and female human capital and hence the 
degree of gender stratification in economic roles. This pleads for deeper investigation.

Human capital theory also gives inadequate attention to the distribution of human capital development responsibilities among social actors on the labor supply side alone. The literature on the development of general human capital, including the works of Becker ([1964] 1975, 1981), Mincer (1974), Mincer and Polachek (1974), and Polachek (1976) centers on individuals acting in their own behalves or on households acting in behalf of the aggregated utilities of household members. But the degree to which the individual has control over the development of his or her human capital vis-à-vis parental control depends critically on the life-cycle timing of human capital investment decisions-early investments imply greater parental control, whereas later ones give a greater degree of control to the individual. This timing is dependent on the institutional context and its cross-cultural variability.

In discussions of human capital development in industrial societies, then, human capital theory tends to view the individual as an autonomous decision maker vis-à-vis human capital decisions, either fully responsible for such decisions or sharing responsibility with his employer. This vision of human capital development reflects a certain degree of cultural myopia, resulting from the development of theory in the social structural context of the United States with little reference to whether the tenets of the theory hold in other cultural contexts. That is, by holding social structure constant, we are holding constant the specific constraints and opportunity structures that are implicit in the array of social institutions of a particular society, in this case, the United States.

I propose the concept of a human capital development system comprising two dimensions: (1) the social-institutional context of human capital development and evaluation, reflected by the structure of the educational system and the labor market and (2) the structure of exchanges and investments, especially intergenerational ones, within the family as the supplier of labor. For convenience, one can think of the two dimensions as corresponding roughly to the labor demand and supply sides, with processes of selection (labor demand) and processes of socialization and training (labor supply) shaped by the social institutions on each side. Table 1 sketches the two dimensions and illustrates the discussion that follows.

First, I argue that the structures of the educational system and the labor market are critical in gender-stratification processes by virtue of their role in determining whether the timing of human capital investment decisions is diffused or condensed across the individual's life cycle. In a society characterized by diffused timing, the individual is confronted with 
TABLE 1

Dimensions of the Human Capital Development Systems of Japan AND THE UNITED STATES

\begin{tabular}{|c|c|c|}
\hline & $\begin{array}{l}\text { Structure of Educational Institutions } \\
\text { and Labor Markets }\end{array}$ & $\begin{array}{l}\text { Life-Cycle Timing of Human } \\
\text { Capital Investment }\end{array}$ \\
\hline \multicolumn{3}{|l|}{1.} \\
\hline \multirow[t]{3}{*}{ Japan } & $\begin{array}{l}\text { School-level tracking in educational sys- } \\
\text { tem, strong age barriers }\end{array}$ & \\
\hline & & Condensed (rigid) \\
\hline & Internal labor markets & \\
\hline \multirow[t]{4}{*}{ United States } & $\begin{array}{l}\text { Nontracking or within-school tracking in } \\
\text { educational system, weak age barriers }\end{array}$ & \\
\hline & & Diffused (flexible) \\
\hline & External labor market & \\
\hline & Structure of Intrafamilial Exchanges & $\begin{array}{l}\text { Importance of Sex } \\
\text { Preferences }\end{array}$ \\
\hline \multicolumn{3}{|l|}{2.} \\
\hline Japan & $\begin{array}{l}\text { Strong intergenerational implicit con- } \\
\text { tracts }\end{array}$ & $\begin{array}{l}\text { Strong implications of } \\
\text { preference for invest- } \\
\text { ment in sons }\end{array}$ \\
\hline United States & $\begin{array}{l}\text { Weak intergenerational implicit con- } \\
\text { tracts }\end{array}$ & $\begin{array}{l}\text { Weak implications of } \\
\text { preference for invest- } \\
\text { ment in sons }\end{array}$ \\
\hline
\end{tabular}

multiple decision points vis-à-vis his human capital development, distributed throughout early and middle adulthood. Age barriers to reentry to educational institutions or to work organizations are minimal, and interorganizational job-mobility rates are high, which reflects the vitality of an external labor market (in addition to whatever firm-internal labor markets may exist). In such a cultural setting, individuals may differ greatly in their life-cycle patterns of human capital development-some individuals may leave school and general educational training, enter the workplace, later return to school, then reenter the workplace. Others may finish school and begin work with one employer, with whom they will remain for their working lives. I do not mean to deny that there may be important economic consequences of the path one chooses, nor that both the opportunity and the willingness to pursue a "typical" life schedule may be correlated with social class, ethnicity, and other variables. My point is that recognition of individual variation in the life-cycle timing of investments is built into social institutions (the educational system and 
work organizations) and ratified by social norms. Such a relatively flexible setting allows those people (generally, women) heavily involved in family commitments to alternate among education, family, and laborforce activities across the life cycle. This type of cultural setting is represented by the contemporary United States.

In contrast, in a society characterized by condensed timing, as structured by the educational system and the labor market, there are a few key points in the life cycle of all individuals when human capital development decisions are critical. Such a setting is characterized by a highly competitive and tracked educational system with strong age barriers, and the actual or ideological predominance of internal labor markets over the external labor market. Severe economic disadvantages accumulate for people who do not succeed in the series of structured "contests" (Turner 1960) at different points on the educational ladder or in the contest on entering the labor market, and these failures cannot be redeemed by further human capital investments by the individual later in the life cycle. This description characterizes a setting such as Japan. A highly educated Japanese woman in her early 40s, interviewed in Tokyo during fieldwork, spontaneously offered the following summary of Japanese life-cycle stages: "It is like a life plan that [we Japanese] have" (Brinton 1986b). The normative significance of this statement can be appreciated if one imagines the extreme unlikelihood of an American's offering to sum up the "life plan" of all Americans.

The second dimension of a human capital development system is the pattern of exchanges and investments that take place in the family, especially between generations. The investments in and preparations for their male and female children that parents are willing to make will influence the extent to which the two sexes are able to compete successfully in educational contests and the contest for entry-level positions in the labor market. ${ }^{6}$ In cultural settings where parents (1) are motivated to invest in at least one child for future returns such as old-age support, (2) have resources for investment, and (3) perceive the labor market to be sex discriminatory, they will favor investments in sons over daughters. This describes, in short form, Japan. Obviously, the motivations for investment and the perception of a sex-discriminatory labor market are both dependent on exogenous forces, such as alternative sources of old-age support and the existence and continuation of sex discrimination in employment. Likewise, the availability and use of resources for educational

\footnotetext{
${ }^{6}$ See the work of Ben-Porath (1980) and an interesting empirical examination of both intergenerational exchange and cross-sibling exchange in Taiwan by Greenhalgh (1985).
} 
investment require a moderate level of income, the perception that directing this income into educational investments will generate returns of some sort (not necessarily pecuniary), and the availability of private schooling. ${ }^{7}$ I argue that the Japanese case fulfills these three conditions to a greater degree than the American case, therefore predisposing Japanese parents to make sharper distinctions between sons and daughters in their allocations of resources. This, then, gives sons an edge in both educational and labor-market-entry competition.

Figure 1 summarizes the overall argument by showing schematically how a social-institutional environment (comprising the two dimensions of the human capital development system) and a normative structure or environment direct the strategic actions of decision makers in the human capital development process, thereby shaping gender stratification in the economy. In stressing the human capital development process, this article attempts to explain not only the conditions under which men and women acquire different amounts of human capital but the conditions under which their human capital is evaluated differently. Figure 1 is intended as a guide to the principal theoretical arguments. Before proceeding with those arguments, I discuss the choice of Japan as a case that contrasts with the United States in gender-stratification patterns.

\section{JAPAN AND THE UNITED STATES: CONTRASTS IN GENDER STRATIFICATION}

In gender stratification, Japan is an important case. The female laborforce participation rate $(48.7 \%$ in 1985$)$ is equal to that in other major industrial economies. But Japan is otherwise a persistent outlier among industrial societies, demonstrating a greater male-female wage differential and more pronounced sex segregation across a range of indicators, including employment status and occupation (Brinton 1986b). In a study of occupational sex segregation in 12 industrial nations, Roos (1985) found that Japan exhibits the greatest difference in the average prestige of men's and women's jobs (women's jobs have significantly lower prestige) and the greatest sex difference in the occupational wage rate. (See Roos [1985, pp. 36-37] for explanation of the construction of the occupational wage-rate scale.) Japan also has the most pronounced "double peak" age

${ }^{7}$ There is not space here to discuss the literature on intergenerational wealth flows (Caldwell 1976) and altruism (Becker 1981; Willis 1982). The implicit approach taken in this paper is that the concept of altruism becomes unnecessary if one takes into account the nonpecuniary returns from investment in children, such as prestige and honor. This theme is being developed in work in progress on the strength of implicit contracts in families and firms in Japan. 


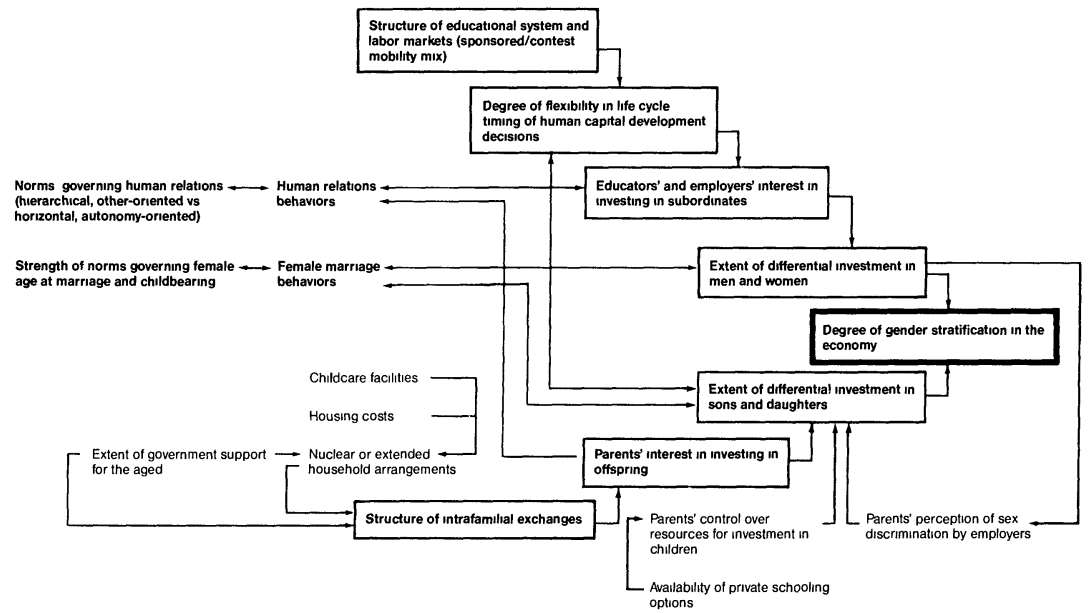

FIG. 1. - The structure of a human capital development system and exogenous factors.

pattern of female labor-force participation, with large numbers of women exiting the labor force upon marriage or the birth of the first child and reentering once the last child enters school. Japan is the only industrialized country where never-married women have an occupational wagerate advantage over married women, which suggests the applicability of a human capital approach that views household and market labor as competing demands for women (Becker 1981).

Two indicators of gender stratification are particularly relevant for my emphasis on human capital investments in the educational system and the workplace: the relative educational attainments of men and women and the relative proportions of each sex that are in high-status/high-income occupations in the business sector. Table 2 indicates that American women achieved on average a higher level of education than men several decades ago. In contrast, rates of high school entrance for Japanese men and women equalized around 1970 (with women's rate slightly surpassing men's), but men's and women's educational paths diverge sharply after high school. Whereas high school seems to have become the minimum acceptable level of education for both sexes in Japan, significantly more men $(38.6 \%)$ go on to four-year universities than do women (13.7\%). If we add in the junior college level, rates of higher educational attendance for women are only slightly lower than for men $(34.5$ vs. 40.6$)$. But it is important to recognize that junior college attendance in Japan is almost exclusively a female phenomenon, with many junior colleges concentrating on home economics, fashion design, English or French literature, and 
TABLE 2

Educational Attainment of Men and Women in the United States and Japan

\begin{tabular}{|c|c|c|c|c|c|c|c|}
\hline & & & & \multicolumn{3}{|c|}{$\begin{array}{c}\text { MEDIAN YEARS OF } \\
\text { SCHOOLING COMPLETED }\end{array}$} & \\
\hline & & & & Males & & Females & \\
\hline \multicolumn{8}{|c|}{ United States: } \\
\hline 1940 & $\ldots \ldots$ & $\ldots \ldots$ & $\ldots \ldots \ldots \ldots$ & 8.6 & & 11.0 & \\
\hline 1952 & $\ldots \ldots$ & $\ldots \ldots \ldots$ & $\ldots \ldots \ldots$ & 10.6 & & 12.0 & \\
\hline 1962 & $\ldots \ldots$ & $\ldots \ldots \ldots$ & $\ldots \ldots \ldots$ & 12.1 & & 12.3 & \\
\hline 1970 & $\ldots \ldots$ & $\ldots \ldots$ & $\ldots \ldots \ldots \ldots$ & 12.4 & & 12.5 & \\
\hline 1975 & $\ldots$ & . & $\ldots \ldots \ldots$ & 12.6 & & 12.6 & \\
\hline \multirow{3}{*}{\multicolumn{2}{|c|}{1981}} & $\cdots$ & $\ldots \ldots \ldots$ & 12.7 & & 12.7 & \\
\hline & & \multicolumn{2}{|c|}{$\begin{array}{l}\text { PROPORTION ENTERING } \\
\text { High SCHOOL }\end{array}$} & \multicolumn{2}{|c|}{$\begin{array}{l}\text { Proportion ENTERING } \\
\text { Junior COLLEGE }\end{array}$} & \multicolumn{2}{|c|}{$\begin{array}{c}\text { PROPORTION ENTERING } \\
\text { UNIVERSITY }\end{array}$} \\
\hline & & Males & Females & Males & Females & Males & Females \\
\hline \multicolumn{8}{|l|}{ Japan: } \\
\hline 1955 & $\cdots$ & 55.5 & 47.4 & 1.9 & 2.6 & 13.1 & 2.4 \\
\hline 1960 & $\ldots \ldots$ & 59.6 & 55.9 & 1.2 & 3.0 & 13.7 & 2.5 \\
\hline 1965 & $\ldots$. & 71.7 & 69.6 & 1.7 & 6.7 & 20.7 & 4.6 \\
\hline 1970 & $\ldots$. & 81.6 & 82.7 & 2.0 & 11.2 & 27.3 & 6.5 \\
\hline 1975 & $\ldots \ldots$ & 91.0 & 93.0 & 2.6 & 19.9 & 40.4 & 12.5 \\
\hline 1980 & $\ldots \ldots$ & 93.1 & 95.4 & 2.0 & 21.0 & 39.3 & 12.3 \\
\hline 1985 & $\ldots \ldots$ & 92.8 & 94.9 & 2.0 & 20.8 & 38.6 & 13.7 \\
\hline
\end{tabular}

SoURCE.-United States: England and Farkas 1986. Japan: Ministry of Education $1985 b$.

NotE. - Because the dropout rate is so low, Japanese educational statistics are customarily reported in terms of the proportions entering each educational level.

other appropriately "feminine" courses of study. Thus, the gender gap in education remains large in Japan.

When we turn to the occupational structure, the proportions of men and women in managerial occupations may be taken as a general indicator of the relative position of men and women in high-status/highincome jobs in the business sector. Further, an examination across cohorts of the proportions of men and women in the labor force who are managers offers a brief assessment of the probability at each age of being in a managerial occupation. As shown in table 3, in the United States $10 \%$ of all employed men are classified as managers, compared with $5 \%$ of all employed women. In Japan, these figures are $7 \%$ and .8\%, respectively. In short, American men are about twice as likely to become managers as are American women, whereas Japanese men are about 10 times more likely to become managers than are Japanese women. Some observers have questioned the validity of managerial statistics for the United 
TABLE 3

Proportion of Employed Persons in Managerial Occupations by Age Group

\begin{tabular}{|c|c|c|c|c|}
\hline \multirow[b]{3}{*}{ TOTAL } & \multicolumn{2}{|c|}{ United States } & \multicolumn{2}{|c|}{ JAPAN } \\
\hline & Males & Females & Males & Females \\
\hline & .10 & .05 & .07 & .008 \\
\hline \multicolumn{5}{|l|}{ Age group: } \\
\hline $15-19 \ldots \ldots \ldots$ & .01 & .01 & .0003 & .00001 \\
\hline $20-24$ & .04 & .03 & .002 & .0004 \\
\hline $25-29 \ldots \ldots \ldots \ldots \ldots$ & .07 & .05 & .01 & .001 \\
\hline $30-34 \ldots \ldots \ldots \ldots \ldots$ & .11 & .06 & .03 & .004 \\
\hline $35-44 \ldots \ldots \ldots \ldots \ldots$ & .13 & .06 & .08 & .007 \\
\hline $35-39 \ldots \ldots \ldots \ldots$ & $\ldots$ & $\ldots$ & .07 & .006 \\
\hline $40-44 \ldots \ldots \ldots \ldots$ & $\cdots$ & $\cdots$ & .10 & .008 \\
\hline $45-54 \ldots \ldots \ldots \ldots \ldots$ & .13 & .06 & .12 & .01 \\
\hline $45-49 \ldots \ldots \ldots \ldots$ & $\ldots$ & $\ldots$ & .12 & .01 \\
\hline $50-54 \ldots \ldots \ldots \ldots$ & .. & $\cdots$ & .13 & .01 \\
\hline $55-59 \ldots \ldots \ldots \ldots \ldots$ & .12 & .06 & .13 & .02 \\
\hline $60-64 \ldots \ldots \ldots \ldots \ldots$ & .11 & .06 & .12 & .02 \\
\hline Construction $\ldots \ldots \ldots \ldots$ & .06 & .07 & .07 & .03 \\
\hline $\begin{array}{l}\text { Wholesale and retail } \\
\text { trade } \ldots \ldots \ldots \ldots \ldots\end{array}$ & .13 & .06 & .09 & .01 \\
\hline $\begin{array}{l}\text { Finance, insurance, } \\
\text { and real estate }\end{array}$ & .21 & .08 & .15 & .02 \\
\hline
\end{tabular}

SourCE.-U.S. Census of Population 1980; Population Census of Japan 1980.

NOTE.-Figures for Japan represent people classified as "managers and officials." This category includes government officials, directors of companies and corporations (non-self-employed), and other managers and administrators (self-employed). The largest group is comprised of people in the second subcategory ("directors"). Figures for the United States represent people classified in "executive, administrative, and managerial occupations." For purposes of comparison with Japan, the subcategory "management-related occupations" was deleted.

States, suggesting the possibility of inflated statistics for minorities in industries that have been heavily monitored by the Equal Employment Opportunity Commission (Smith and Welch 1984). ${ }^{8}$ The lower half of table 3 shows data for three specific industries in the United States and Japan, chosen because of their low reporting rates to the EEOC and the probable absence of any upward bias in the managerial rates for women. (Figures show the proportion of each sex in each industry that is employed as managers.) Despite wide variation across industries in the gap

${ }^{8} \mathrm{I}$ appreciate the comments of an anonymous reviewer who brought this point to my attention. 
between males and females, in all instances the gap remains narrower for the United States than for Japan.

Table 3 also shows that the proportion of the employed population in the United States that works as managers is quite stable from the 30-34 cohort on, whereas in Japan the probability of being a manager continues to increase until a much later age (50-54). This suggests that seniority and experience are more important as qualifications for management in Japan than in the United States. ${ }^{9}$ As I will discuss, the two qualifications entail processes of investment in the Japanese workplace that work against the equal attainment of women.

In sum, women are less apt to attain university education or managerial positions in Japan, outcomes that are the culmination of human capital investment processes involving the individual and the family on the one hand, and the individual and the employer on the other. I turn now to consider the social-institutional context of human capital development in Japan, as contrasted with that in the United States.

\section{THE SOCIAL-INSTITUTIONAL CONTEXT OF HUMAN CAPITAL DEVELOPMENT IN JAPAN: EFFECTS ON THE LIFE-CYCLE TIMING OF HUMAN CAPITAL INVESTMENT DECISIONS}

The Structure of the Japanese Educational System: Sponsored Contests

The postwar educational system in Japan is modeled on the 6-3-3 American system, with elementary school taking six years and junior and senior high school each taking three years. Attendance is compulsory only through junior high school, but, as was shown earlier, 93.8\% of Japanese youth currently go on to high school (Ministry of Education 1985b). The superficial similarity between the American and Japanese educational systems masks underlying differences that have to do with both the content of education and the way that students are channeled through the system and into the labor market.

The purpose of Japanese education is to equalize the individual's talents across subject areas so that he can pass standardized examinations for successive levels of education. The first entrance examination, or "contest," is for high school; in contrast to the American system, each school district has several high schools, often of varying academic qual-

\footnotetext{
${ }^{9}$ One could, of course, argue that a changing occupational structure with advanced industrialization might increase the proportions at younger ages that have access to managerial jobs. This would be analogous to arguing for an interpretation that stresses period effects rather than cohort effects; it is impossible to separate out the two in a cross-sectional table such as this one. If such an interpretation were correct, though, one would expect Japan and the United States to exhibit opposite age patterns than they in fact do.
} 
ity, and the students must pass an entrance examination in order to be admitted. Once they are admitted, egalitarian principles predominate in the sense that there is no system of tracking. However, the hierarchy of schools in a district itself represents tracking, with the school as the unit of tracking. The goal is to enter a "good" high school in order to be able to prepare for the next contest, be it the exam for entering a "good" company or the exam to enter a "good" university and later the job market. Rohlen discusses the historical articulation between the educational system and the firm in Japan: "A simple but powerful formula that has dominated Japanese secondary education ever since [the late 19th century] was thus established: the difficulty of a school's entrance exams is the crucial measure of its students' talent. Employers chose to let this criterion of school reputation, rather than an individual's grades or subjects studied, guide their selection of personnel for managerial jobs. Entrance exams thus became the route to success. For the upper and middle classes, it was the practical way to the best jobs, whether the subjects studied ever proved practical or not. The formula has not changed in a hundred years" (1983, pp. 58-59).

In contrast, the American educational system functions to a somewhat greater extent as a job-preparation site, focusing more heavily from early education onward on discovering the individual's own talents and creative abilities and helping them to blossom. ${ }^{10}$ Related to the function of education is the presence or absence of age barriers. There is strong social pressure in Japan to complete one's education "on schedule." In contrast, general social acceptance and a relative absence of age barriers in the American educational system make it possible for the individual to continue to invest in his human capital even after becoming an adult (Hogan and Mochizuki 1985).

Table 4 demonstrates the rapid drop-off in the proportions of the population in school in Japan after age 22. The rate halves between ages 22 and 23 and then again between 23 and 24 , becoming trivial (.8\%) in the 25-29 age group. In contrast, the proportions attending school in the United States drop at a much more uniform rate over a wider age span and reach the level at ages 40-44 that exists in Japan at age 24.

This difference in the age structure of education also reflects the greater importance of graduate and professional school education in the United States. A rough indicator of the importance of postsecondary specialized schools other than universities can be obtained by calculating the proportion of the post-high school student population attending these schools

${ }^{10}$ This was most clearly seen in the move during the 1960s in the United States toward innovative schools and the publication of such books as Sheldon Leonard's Education and Ecstasy. 
TABLE 4

Proportion of the Population in School, by Age Group

\begin{tabular}{|c|c|c|c|}
\hline \multirow[b]{2}{*}{ AGE } & \multirow[b]{2}{*}{$\begin{array}{c}\text { United States } \\
(\%)\end{array}$} & \multicolumn{2}{|c|}{ JAPAN } \\
\hline & & $\begin{array}{c}\text { School Only } \\
(\%)\end{array}$ & $\begin{array}{c}\text { School + Work } \\
(\%)\end{array}$ \\
\hline$\ldots \ldots \ldots \ldots$ & 62.3 & 66.3 & 69.4 \\
\hline $19 \ldots \ldots \ldots \ldots \ldots$ & 42.3 & 42.6 & 47.2 \\
\hline $20 \ldots \ldots \ldots \ldots \ldots$ & 34.3 & 33.2 & 37.6 \\
\hline $21 \ldots \ldots \ldots \ldots \ldots$ & 30.6 & 25.2 & 28.9 \\
\hline $22 \ldots \ldots \ldots \ldots \ldots$ & 23.9 & 17.5 & 20.1 \\
\hline $23 \ldots \ldots \ldots \ldots \ldots$ & 18.3 & 8.0 & 9.4 \\
\hline $24 \ldots \ldots \ldots \ldots \ldots$ & 15.6 & 3.5 & 4.3 \\
\hline $25-29 \ldots \ldots \ldots \ldots$ & 10.3 & .8 & 1.0 \\
\hline $30-34 \ldots \ldots \ldots \ldots$ & 7.1 & .1 & .2 \\
\hline $35-39 \ldots \ldots \ldots \ldots$ & 4.8 & .05 & .06 \\
\hline $40-44 \ldots \ldots \ldots \ldots$ & 3.7 & .02 & .03 \\
\hline $45-54 \ldots \ldots \ldots \ldots$ & 2.2 & .02 & .02 \\
\hline
\end{tabular}

SourCES.-U.S. Census of Population 1980; Population Census of Japan 1980.

(as opposed to university). For the United States, this ratio is .37, while in Japan it is only .20 (United Nations 1982b). This reflects the fact that, for most Japanese individuals, the timing of skill development coincides with entrance into a work organization immediately after completion of a general educational background.

The Japanese educational system functions to prepare the individual to obtain a credential that will facilitate entrance into an organizational setting (such as marriage or the firm) and the set of human relations embedded in it, whereas the American educational system prepares the individual for a particular role or job without as much reference to the organizational setting in which the role will be carried out. In America, the job itself rather than the organizational setting acts as a motivator. The Japanese educational system prepares individuals to be in a position to enter an organization and be the worthy recipients of more human capital investment from those of higher status, in the form of on-the-job training and grooming for advancement within the organization. Firms themselves conduct "contests" for job applicants in the form of extensive interviewing and testing procedures. ${ }^{11}$

${ }^{11}$ The salience of these tests is evidenced by the shelfful of books in any Japanese bookstore on techniques of job interviewing. The overriding importance of passing school entrance exams as an intermediate stage to "success," however, is evidenced by the devotion of a much larger section in the typical bookstore to techniques for passing the entrance exams. 
The emphasis on placement in a particular work environment upon graduation from high school or a successive level of schooling (vocational school, junior college, or university) is reflected in finely tuned institutional mechanisms of matching students to jobs, mechanisms that depend on the cooperation of teachers, students, employers, and parents. Job placement, in short, is heavily sponsored. (Although this has been demonstrated in the United States for professional schools, the striking aspect of the Japanese situation is that it occurs across all secondary and tertiary school levels: high school, junior college, vocational school, and university.) Schools stand to gain prestige by placing their good students with reputable firms, prestige both in the community (thereby attracting strong applicants for the entrance examination) and with employers (thereby attracting recruiters for the following year). Parents gain peace of mind seeing their children step into "good" jobs immediately upon graduation. Students gain the advantage of not having to pound the pavement in an extensive and relatively autonomous job search. (American youths have a turnover rate roughly three times that of their Japanese counterparts [Ohashi 1981].)

In summary, in the American system the individual has considerably more opportunity to invest in his own human capital at different points in the life cycle than he does in Japan. The structure of the Japanese educational system means that the individual must win a series of what can be termed sponsored contests. The probability that this will occur is increasingly linked in parents' minds to their sponsorship of children through investment in private education, which we will consider when we turn to the discussion of intrafamilial exchanges. Likewise, sponsorship by individual educators and the school in matching the individual to a job in a company is also institutionalized. These sponsored contests relate to the development of general human capital and are complemented by the institutionalization of the sponsored development of specific human capital in work organizations, or what I term sponsored mobility, especially in the early years of an individual's work career.

Who loses, then, in this structure of successive contests? This question can be approached only by recognizing that employer demands are a principal driving force behind the contests in the educational system. In an organizationally based economy where internal labor markets are strong and much job training occurs in the firm, employers seek employees who will have low turnover rates and who will also blend in well socially with each other. These demands, coupled with strong social norms about marriage and childbearing, which I will discuss shortly, mean that employers tend to reserve the "good" starting jobs for men, men who have been sponsored by parents and educators in their progress 
through the series of educational contests. ${ }^{12}$ To see this, we turn now to a discussion of the Japanese employment system.

The Structure of the Japanese Employment System: Sponsored Mobility in Internal Labor Markets

Low interfirm mobility, seniority-based wage and promotion systems, and firm-specific training in Japan combine to make an individual's first job crucial in terms of getting on a successful career track (Brinton $1986 a$ ). It is now widely acknowledged that the Japanese permanent employment system, with its three "pillars" (seniority-based wage payments, enterprise unions, and lifetime employment), became firmly established by the second decade of the postwar period and that internal labor markets are a characteristic feature of the system (Koike 1983; Shimada 1983). ${ }^{13}$ Although the external labor market has loosened somewhat in recent years, the few existing studies of interfirm mobility, all concerning male behavior, consistently document a lower frequency of employer changes in Japan than in the United States, particularly once a person reaches the late 20s (Cole 1979; Hashimoto and Raisian 1985). In a careful investigation of employment tenure in Japan and the United States, Hashimoto and Raisian report that, while employer-employee attach-

12 The degree to which sponsorship vs. individual ability and achievement accounts for success in the Japanese educational system is hotly debated among both Japanese and American scholars. See, e.g., the contrasting views of Cummings (1980), Rohlen (1983), and Seiyama and Noguchi (1984). This relates directly to the issue of whether rates of intergenerational occupational mobility are lower in Japan than in other industrial countries. In fact, comparative studies of social mobility do not depict Japan as an outlier (Tominaga 1979; Grusky and Hauser 1984). However, there is no a priori theoretical reason why high rates of intergenerational mobility and a high degree of gender stratification cannot exist side by side in the same economy. This can be seen most clearly if we understand intergenerational mobility to be related to processes of inheritance/disinheritance between generations, whereas gender-stratification processes originate in allocation patterns among siblings.

${ }^{13}$ The origins of the permanent-employment system have engendered lively debate among Japan specialists, which has resulted in the currently prevailing view that its development can be traced to a combination of labor supply conditions, employers' conscious reinterpretation of elements of the traditional cultural heritage, and the state's support of employer associations toward this end. Cooperation between employers and the state was particularly critical in the period between World War I and World War II, when embryonic industrial labor unions were seen as a potentially serious cause of political turmoil (Crawcour 1978; Fruin 1978). The role of the state in human capital development is not dealt with explicitly in this article, except in two points: (1) the endorsement of internal labor markets and (2) the absence of strong social welfare provisions, such that parents are implicitly encouraged to invest in the "quality" of their children for old-age security reasons. (The latter point is discussed later in the paper.) 
ment in the United States is not as weak as is popularly portrayed in comparisons with Japan, the typical American male worker nevertheless holds twice as many jobs during his working life as his Japanese counterpart. Nor is job stability in Japan limited to male employees in large firms. From data on firm size and job tenure, Hashimoto and Raisian conclude that "although job tenure is longer in large Japanese firms, it is quite long even in the tiny and small firms. This finding raises doubts about the popular belief that life-time employment is only a large-firm phenomenon" (1985, p. 727).

Low interfirm mobility is coupled with employer investment in employees' purportedly specific human capital through on-the-job training and rotation among various positions within the work organization. For the employee, these investments translate into career development in the firm and, on average, a steeper wage profile than would obtain were he to leave the firm (Shimada 1981).

The synopsis of human capital development in the firm sketched here corresponds, of course, to the now-stereotypical view of large Japanese work organizations. What is perhaps not so obvious is the extent to which this model of human capital development tends to be accepted as the normative ideal - by the Japanese government, by workers themselves, and by employers of varying size firms. Popular ideology, as well as that of the government, has supported the idea that participation in such a system is a privilege and that interfirm mobility is "a response to defective human relations" (Office of the Prime Minister 1973, p. 27). Despite recent changes in the economy, firms with internal labor markets continue to be the employment ideal for the best and brightest of high school and university graduates. In a 1983 survey conducted by the Nihon Recruit Center, a private Japanese research organization, $61.9 \%$ of male university seniors hoped to be employed in a large firm (daikigyo) in the future (Nihon Recruit Center 1983). This was an increase of $10.8 \%$ since 1975.

Small- and medium-sized firms in Japan demonstrate human capital development patterns that are strikingly similar to those in large firms in on-the-job training, promotion from within the firm, and little midcareer recruitment from outside the firm. In a survey of 5,200 companies carried out by the Ministry of Labor (1981), $97 \%$ of companies employing over 1,000 workers carried out educational training, and $96 \%$ carried out periodic job rotation. The figures are lower for smaller firms, but even among firms of 100-299 employees, $81 \%$ carried out educational training and $79 \%$ carried out job rotation. These statistics complement Hashimoto and Raisian's findings regarding the tendency for long-term employment in small as well as large Japanese firms.

On-the-job training has been the dominant mode of skill formation in 
Japanese industry in the post-World War I period (Koike 1983). The distribution of training among employees is subject to a great deal of discretionary power by Japanese managers, and in this way the system shares some common points with earlier apprenticeship systems. Managers and foremen, as representatives of the company, have considerable leeway in distributing work responsibilities and developing workers' human capital. Koike remarks on the hierarchical interpersonal relations involved in skill development and the degree of control exercised by foremen: "When the operation of the system is observed in more detail, it is recognized that in practice the system is less egalitarian than it first appears. A young recruit who joins a work group following formal training is usually backed up by the sub-foreman for a period of time-say, several months. Even after that, he is instructed and attended by a senior worker who occupies the next position in the rotation sequence" (1983, p. 43). Koike's international field observations in manufacturing plants lead him to conclude further that "the foreman in Japanese labor markets is much more involved than his Western counterpart in a worker's career" (1983, p. 46).

Given this predominant type of human capital development, employers are critical actors. They have resources to invest in skill development and have an incentive to invest in those workers whom they expect to remain with the firm. Employers understand that such employees are more likely to be men than women. ${ }^{14}$ Among Japanese employers who state that there are no promotional possibilities for women in their firms $(43.7 \%$ of all employers [Ministry of Labor 1985]), more than one-third attribute this to the fact that they anticipate a low number of continuous working years for women.

To summarize, the structure of the Japanese employment system compresses the timing of human capital decisions into a relatively short period. Critical job training is delayed until young adulthood, when a person enters the labor market and a specific organizational environment. This coincides with the period of marriage and childbirth for women, a time when they are likely to exit the labor force because of the competing demands of household and market labor. By the time women reenter the labor market in their mid-30s or early 40s, employers' crucial human capital investment decisions have been carried out, and men of the same age are years ahead in training and promotions. Although this is true in industrial societies in general, the dovetailing of the critical employmenttraining period and the period of young adulthood family responsibilities

${ }^{14}$ This illustrates the now-familiar notion of statistical discrimination, whereby an individual with certain ascriptive characteristics (e.g., sex) is judged on the basis of the average attitudes and behaviors of the origin group (Arrow 1973; Phelps 1972). 
for women is particularly acute in Japan and is further exacerbated by strong normative pressure regarding age at marriage and childbearing for females (Morgan, Rindfuss, and Parnell 1984). Japan may not be qualitatively unique in the life timing that is encouraged by its institutions, but the institutional articulation between education and work organizations is strong, coherent, and pervasive and leads to very low variance across individuals in the timing of life-cycle transitions.

\section{The Structure of Intrafamilial Implicit Contracts in Japan}

We have seen that the structure of the educational system and its function in channeling workers into stable jobs creates a potentially strong role for Japanese parents as sponsors of their children's early human capital development. This is heightened by the strength of Japanese intergenerational ties and exchanges between parents and children across the life cycle, the second dimension of a human capital development system. Research on the Japanese family has repeatedly emphasized the dominance of the parent-child tie (a hierarchical, or vertical, relation) over the tie between spouses (Blood 1967; Vogel 1967; Coleman 1983).

The strength of the intergenerational bond extends into the financial as well as the emotional sphere, with many parents anticipating help in both areas in old age. Retirement benefits from companies typically come in the form of a lump-sum payment. The retirement age is the late $50 \mathrm{~s}$ in most companies, and a gap of 5-10 years exists between retirement and the age of eligibility for public pensions, which causes many older Japanese to search for alternative employment during these years (Martin 1987). Under conditions of limited public support for the aged, parents have strong incentives to invest in at least one child in order to ensure financial stability in old age. The intergenerational bond across the life cycle is further supported by factors such as high housing costs and inadequate child-care facilities, which make extended-family residence desirable for many families (Morgan and Hirosima 1983).

Japanese parents' expectations about sons and daughters remain quite distinct. Opinion polls demonstrate that Japanese prefer to have a son over a daughter if given a choice. ${ }^{15}$ Further, among parents who antici-

15 To the question, "If you were only able to have one child during your lifetime, would you want a son or a daughter?" $44.3 \%$ of a national random sample of Japanese adults replied that they would want a son, and only $25.5 \%$ replied that they would want a daughter (the remaining $31.2 \%$ were unsure or did not prefer one to the other. [Office of the Prime Minister 1979]). Strong Japanese sex preferences are even more striking when compared with the weak sex preferences reported in other industrial nations (Office of the Prime Minister 1982a). 
pate relying on their children in the future, the majority anticipate financial reliance on a son and emotional reliance on a daughter. When parents with at least one child of each sex are asked whether they hope to live with any of their children in old age, $37.8 \%$ state that they hope to live with a son, $7.8 \%$ hope to live with a daughter, and the rest anticipate not living with any of their children. Moreover, when asked about financial support, $74.6 \%$ of parents report that they hope to receive financial help from a son in old age, but only $6.4 \%$ have this expectation from a daughter. This is balanced by parents' greater expectation of emotional support from daughters $(46.3 \%)$ than sons (31.1\%) in old age (Brinton 1986b).

Sex segregation in parents' expectations about their children's future roles is undoubtedly based on "traditional" values to some extent. But these expectations appear to be reinforced by two current trends as well. The first has to do with perceptions of sex discrimination in the labor market, and the second, with an increase in the popular perception that cram schools are a necessary investment to help children pass the school entrance exams. I examine each of these briefly.

First, there is a widespread perception that sex discrimination is commonplace in Japanese labor markets. A 1984 national opinion poll (conducted by the Yomiuri Shimbun) revealed that $79.6 \%$ of the Japanese population believes that women are treated "disadvantageously" in hiring decisions, and $83.6 \%$ feels that this extends to decisions about job rotation and promotion. Moreover, there is also evidence for popular perception of the low marginal utility of higher education for women entering the job market (Nihon Recruit Center 1984).

Given the incentives to rely on the younger generation for economic and emotional support and the perception that sex discrimination is a social fact, it makes sense for parents to differentiate their investments in sons and daughters. Sons have a greater chance of financial success, and this continues to have practical significance for parents. ${ }^{16}$ This fact, added to the importance of graduation from a prestigious school for entering a large firm, means that it is rational for parents to use their financial and psychological resources to further the education of sons over daughters.

In order to ensure sons' financial success, it is increasingly believed that resources should be devoted to private education. This is the second current phenomenon that may be leading to greater gender stratification

${ }^{16}$ See Becker and Tomes (1979) and Rosenzweig (1982) for discussions of the relative endowments of children in the same family and effects on the intrafamily distribution of resources; Rosenzweig focuses specifically on gender as an endowment. 
in the economy. In the past 20 years, there has been a trend in Japan toward the privatization of educational expenses through private schools and various forms of "extraschool" schooling such as $j u k u$ (private tutorial schools), yobiko (examination-preparation schools), and katei kyoshi (private tutoring) (Yamamura and Hanley 1975; Rohlen 1977). Household expenditures on extraschool schooling have shown a fourfold increase in recent years, from $4.7 \%$ of total household expenditures on education in 1965 to $18.7 \%$ in 1982 (Office of the Prime Minister 1983). ${ }^{17}$ Approximately $35 \%$ of the successful applicants in 1980 to Tokyo University, the pinnacle of Japanese universities, were taking the test for the second time and had sat out a year as ronin (literally, masterless samurai) (Rohlen 1983). The great majority of ronin are males whose parents support them financially in full-time study for the entrance exam. A popular Japanese expression for studying for the entrance exam is nininsankyaku, which means three-legged race; this is a poignant reminder that passing the entrance exam is not solely an individual child's endeavor. Rohlen sums up the psychological background of educational decisions in the early adolescent period as follows: "Many important virtues . . . are tied together at a formative period and are motivated largely by a rather selfish individual desire to get ahead (or as many put it, 'to not fall behind'). Whether the desire is the parents' or the child's is never that clear, and this too seems characteristically Japanese. This desire is hardly individualistic in the sense of stemming from individual choice or the uniqueness of personality" $(1983$, p. 109).

Strong sex segregation in educational aspirations for children supports the hypothesis of parental preference for sons' higher education over daughters'. As shown in table 5, 73.0\% of Japanese mothers would like their sons to go to university, whereas only $27.7 \%$ hold this aspiration for their daughters. For a daughter, $28.9 \%$ of mothers feel that junior college is the best alternative, and $26.3 \%$ feel that high school is sufficient. The data for the United States vary markedly from these results: $68.9 \%$ of mothers hold university aspirations for their sons, and $65.8 \%$ hold university aspirations for their daughters, which reflects an almost identical belief in the value of university education for the sexes (whatever the purpose of that education may be). In fact, Japan is the only country in the survey that shows a substantial gap between educational aspirations for sons and daughters. Unfortunately, the data set does not include other

${ }^{17}$ The proliferation of extraschool schooling is evidenced by Japanese government statistics showing that the proportion of Japanese children at the ninth-grade level whose formal education is supplemented by attendance at private tutorial schools has risen to approximately 50\% nationwide and to even higher proportions in urban areas (Ministry of Education 1985a). 
TABLE 5

Mothers' Educational Aspirations For Sons/Daughters

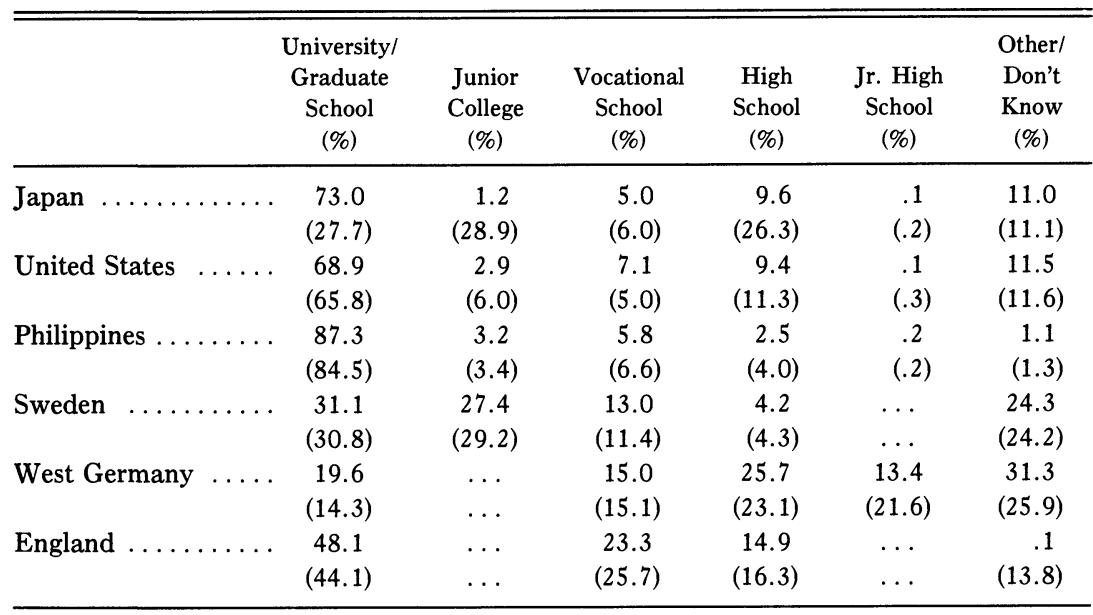

Source.- Office of the Prime Minister, Japan, $1982 a$.

NotE.-Table shows respondents' answers to the question, "What level of education would you like your son to receive?" Figures in parentheses indicate the corresponding educational aspirations for daughters.

East Asian countries such as Taiwan and Korea, where preferences for sons' education may also exceed those for daughters. In the present survey, the sex gap in all other countries spans only a few percentage points (to wit, a maximum of 5.3 in West Germany vs. a huge gap of 45.3 in Japan). The divergence in educational aspirations for sons and daughters also proves remarkably robust across other government surveys of the Japanese population. ${ }^{18}$

To summarize, I have argued that the structure of sponsored contests in the Japanese educational system and labor markets, on the one hand, and the structure of intrafamilial exchange, on the other, constitute a system of human capital development that maintains gender stratification in the economy. I have touched in the discussion on the variety of exogenous mechanisms that affect individual actors' decision making. The picture I have sketched is a complex social-institutional view of the construction of human capital. In addition, the normative environment is

${ }^{18}$ Surveys with similar questions include Kyoiku ni kansuru yoron chosa (Opinion survey on education [Office of the Prime Minister 1982b]) and Hino-shi fujin ni kansuru ishiki chosa (Hino city opinion survey concerning women [Hino Municipal Office 1985]). 
important in two particular ways: (1) the social-institutional system is buttressed by an ideology of human relations that transcends particular institutional settings in Japan (the ideology of hierarchical relations), and (2) norms governing age at marriage and childbirth for women reinforce employers' use of statistical discrimination in hiring, training, and promotion decisions.

\section{THE NORMATIVE ENVIRONMENT}

\section{Norms Governing Human Relations}

A wealth of literature in the Nihonjinron (Japanese national character) tradition deals with the sources and characteristics of "uniquely" Japanese interpersonal relations (Yukawa 1967; Nakamura 1968; Nagashima 1973; Kumon 1982; Hamaguchi 1985). The terms used by Nakane Chie (1970) are the most familiar to Western social scientists. According to her analysis, social relations can be thought of as having either a dominant horizontal or vertical structure, with a horizontal structure involving more interactions among status equals and a vertical structure involving a higher concentration of interactions among people unequal in status (thus, the vertical relation). Japanese social relations epitomize the vertical type.

The most penetrating and analytical attempt to chart the historical sources of Japanese social organization and human relations is in Bunmei to shite no Ie Shakai (Ie society as a civilization [Murakami, Kumon, and Sato 1979]), a massive treatise by three of Japan's leading social scientists. ${ }^{19}$ In their view, the $i e$ (generally translated into English as "household" but used by Murakami et al. as a broader analytical construct) is repeated as a form of organization throughout the contemporary Japanese economy, society, and polity. ${ }^{20}$

For our purposes here, the most significant organizational feature of the $i e$ is functional hierarchy, which "aims at collectively fulfilling some

${ }^{19}$ The book has received several awards in Japan, including the Odaka Prize in 1981 for the best book in sociology. The authors' principal arguments are summarized in English by Yasusuke Murakami, "Ie Society as a Pattern of Civilization" (1984).

${ }^{20}$ The major features of the ie system are (1) "kintractship," or the tendency to recruit like members into the organization and to socialize them as integral members of the group, (2) the construction of the goal of continuation as a collectivity through time, (3) a structure of roles represented by functional hierarchy, and (4) autonomy of organizations, or a high degree of interdependence among group members. These features have been extended by Murakami to the Japanese management system and other organizational forms in modern Japanese society. To Western eyes, this type of social organization is most closely akin to feudalism and in fact is related to Japan's feudal heritage. 
function by assigning a specific part of this function to each individual stratum within the hierarchy" (Murakami 1984, p. 309). This principle of hierarchical role differentiation involves a web of intense, hierarchical interpersonal relations and iterative exchanges across status lines within an organization. These interactions entail investments by older, highstatus group members in younger, lower-status members and corresponding expectations for returns on the investments. These iterated interactions constitute the micro-level processes through which human capital development is encouraged in the larger context of a social institution. In this sense, human capital investment in Japan is inherently other oriented, involving investments in those of lower status and expectations of pecuniary or status returns.

In the discussion of intrafamilial exchange, $I$ illustrated how this logic is played out. But intense personal, hierarchical relations within the Japanese firm are perhaps less obvious and warrant a short description here.

\section{Norms for Hierarchical Relations within the Firm}

Many Japanese and Western observers have argued that human relations within the Japanese firm assume no less importance than structural features. A frequently cited Organization for Economic Cooperation and Development publication in 1977 concluded that the uniqueness of the Japanese industrial relations system lay not so much in its allegedly peculiar institutions, such as lifetime employment, seniority wages, and enterprise unionism, as in what was termed the "fourth pillar"- the "social norms within the enterprise" (cited in Shimada 1983, p. 4).

A great deal of socialization occurs in the Japanese work organization in interactions the employee has with superiors as well as colleagues. Age grading within firms promotes solidarity among members of an entering cohort and creates a clear age hierarchy within the firm, with older cohorts responsible for the informal socialization and training of younger ones. Hiring occurs on a ritualized, fixed schedule: there is a designated season for job hunting (autumn) and a designated season for job starting (April, after graduation from school in March). ${ }^{21}$ The fresh school graduate thus inevitably enters a firm as a member of an age cohort, a phenomenon that has different implications for men and women. Young men do

\footnotetext{
${ }^{21}$ These seasons are preceded by a summer during which many students seriously consider the company they would like to enter and a frenetic early autumn when placement guides listing major Japanese firms are distributed on university campuses. This system is so entrenched and so universal that young Japanese with whom I have spoken expressed surprise that the timing of recruitment into American firms is more flexible-and disbelief that American practices could possibly result in an orderly labor market.
} 
not doubt that they are embarking on a lifetime of work; many of them will remain with the same company for the duration of their working lives (Cole 1979). ${ }^{22}$ Male competition and camaraderie coexist in a kind of symbiotic tension. Japanese men start a new, long chapter in their lives when they enter the working world and a particular organization. In most cases, this is not true for women, who are likely to have several intermittent chapters of outside work in their lives. A statement by a man in his mid-30s illustrates the salience of the workplace for Japanese men: "If a man loses his job or otherwise fails in his work life, his social life crumbles-they are that intimately related. If you correctly understand that, I think you can begin to see the pressures under which Japanese men work. And understanding that helps you to understand the position of Japanese women, too" (Brinton 1986b, p. 148). ${ }^{23}$

Even when women express seriousness about career intentions, their senior colleagues are ill-equipped to train them. As one white-collar worker in his late 20s stated, "There are no senpai [older colleagues or mentors], no models for young female employees and we [men in my age group] don't feel like we can do a very good job" (Brinton 1986b, p. 149). In regard to the civil service, generally touted as the most gender-blind occupational sphere in Japanese society, Lebra states, "Being a risky investment as a career employee, a woman needs a special 'guarantor' responsible for whatever will happen to her" (1981, p. 299). In a system of human capital development based on sponsorship, the scarcity of higherstatus others or guarantors willing to socialize and train female workers perpetuates gender stratification in the labor force. This scarcity is likewise reinforced by the predictability with which Japanese women marry at particular ages and thereby assume an additional commitment (marriage is jokingly referred to in Japan as women's "lifetime employment").

\section{Norms about Age at Marriage for Women}

Over one-half of Japanese women marry "on schedule" (between the ages of 23 and 27), and many Japanese employers feel that they will suffer a

${ }^{22}$ A survey by the Nihon Recruit Center (1985) reported that young male employees are much more likely to state that they feel they are competing with members of their age cohort within the same firm rather than with men who entered other firms in the same year. The same survey reported that nearly one-half $(48.5 \%)$ of young male employees want to remain with the same firm until retirement; another $35.9 \%$ state that it depends on the situation. Only $15.2 \%$ wish to change employers or become selfemployed in the future. The sample was evenly divided between employees in manufacturing and nonmanufacturing firms, and $55 \%$ of the respondents were employed in large firms (1,000 or more employees).

${ }^{23}$ See Atsumi (1979) for a discussion of the role of tsukiai, or informal socializing, in Japanese work life. 
loss of return on investments in the human capital of women who will leave the firm at that point. ${ }^{24}$ The low variance in age at marriage for Japanese women is shown in figure 2. Very few Japanese females marry before age 20 , but by age 27 over three-quarters have married. In contrast, American women marry across a wider age span; over one-quarter have already married by age 20 , and marriages continue apace, so that by age 27 the proportion never married is similar to that in Japan. Both American and Japanese men show large variation in age at marriage, with Japanese men marrying later. Although not shown here, when live birth rates specific for age of mother are compared internationally, Japan again exhibits a low-variance pattern, with a sharp peak in the 25-29year age group (United Nations Demographic Yearbook 1982). ${ }^{25}$

Japanese women are faced with a dilemma, then: they face strong pressures to marry on time yet risk being written off by employers, who will consider them poor risks for investment in human capital through onthe-job training. As long as there is low variation in age at marriage, Japanese employers minimize their risks by using a statistical discrimination rule, judging the timing of marriage (and subsequent quit propensity) by the sex of the job applicant. In this fashion, marriage norms and employer behavior have feedback effects that maintain minimum hiring and promotion opportunities for women and reinforce patterns of gender stratification. ${ }^{26}$

\section{CONCLUSION}

I have focused on the identification of the principal social actors responsible for human capital development and the way in which their incentives, information, and resources lead them to make differential investments and evaluations of the human capital of men and women across the life cycle. The article thus argues for basic differences among societies in the

\footnotetext{
${ }^{24}$ See Brinton (1986b, chap. 7) for ethnographic data on employers' opinions on investing in female workers.

${ }^{25}$ Marini has specified that measurement of social norms requires "(1) information on the acceptability of a behavior within the population of interest and (2) information on the strength of sanctions brought to bear when behavior is unacceptable" (1984, p. 240). I argue that in the absence of direct attitudinal data, demonstration of much lower variance in the timing of a behavior such as marriage in one culture compared with another culture suggests the existence of stronger norms. Ethnographic and survey data on appropriate ages for marriage and childbearing in Japan are discussed in more detail in Brinton (1986b), and comparisons of the variance of age at marriage for American and Japanese women are discussed in McLaughlin and Brinton (1987). ${ }^{26}$ Arrow's $(1973,1976)$ discussion of perceptual equilibrium is relevant to this type of process.
} 


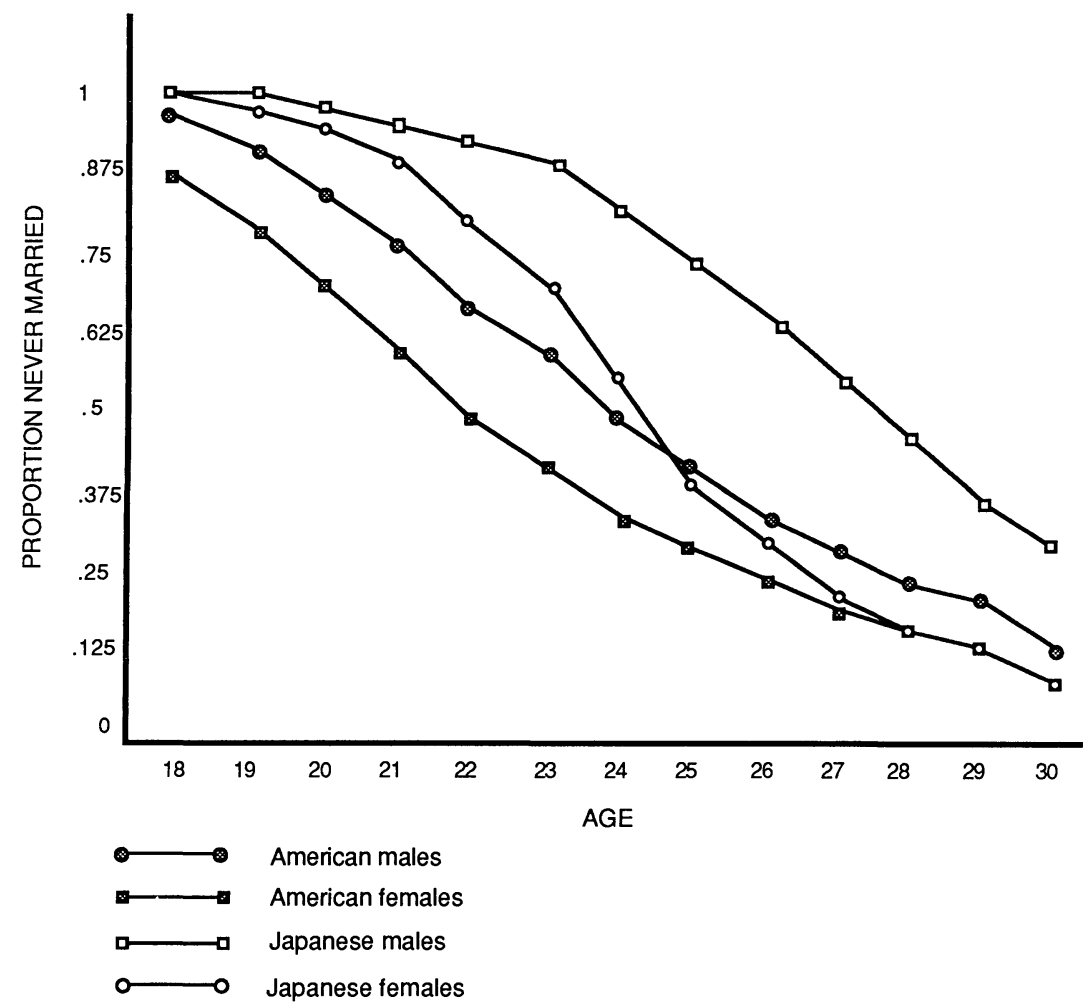

Fig. 2.-Proportion never-married, by age and sex: United States and Japan. (Sources: U.S. Census of Population 1980; Population Census of Japan 1980.)

very processes of human capital development and evaluation rather than focusing on the differential amount of human capital of men and women in different societies and the narrowing of that gap. It is in this respect that the theory is embedded in the social context.

I have argued for the usefulness of thinking in terms of human capital development systems that comprise a dimension reflecting the structure and articulation between the educational system and the labor market and a dimension that involves the structure of intrafamilial exchanges. Japan is a case where, in comparison with the United States, the tight articulation between educational institutions and the labor market and the highly structured series of exams for entrance into schools and firms encourage a high degree of sponsorship and investment in young people's future from those of higher status. There is low variance among Japanese individuals in the life-cycle timing of behaviors that signal adulthood, such as leaving school and entering marriage. Critical human capital 
development decisions are condensed into a few years in the individual's educational and work life, when key individuals have a great deal of control over educational and training resources and also play important roles in directing the individual's own goals and decisions. This is reinforced by a pattern of intergenerational ties and exchanges that encourages parents and employers to make rational decisions based on the expectation of future returns to the social unit (family or firm) in pecuniary form or in the form of prestige. In future work, it will be important to look more closely at the types of nonpecuniary returns and how they affect relative investments in men's and women's human capital. With the identification of the critical social actors involved in human capital development, their incentives, and their information and resources, I have argued here that the type of human capital development system represented by Japan encourages the maintenance of different roles for men and women in the economy. I conclude with some comments on possible sources of change and with suggestions for extensions of the model to other contexts.

A systemic model is not necessarily a static one. Indeed, any number of "pressure points" exist in the web of social-institutional and normative structures discussed here. A few examples serve to suggest the dynamic nature of the model. In 1985, the Japanese Diet passed an equal employment opportunity law that encourages employers not to discriminate on the basis of sex at any stage of the recruitment and employment process. As is typical of much Japanese legislation, the law does not stipulate punishments for offenders but is instead intended as "administrative guidance" for behavior. It is not clear yet what the effects of the law will be on women's employment. To the extent that employers begin to invest more heavily in on-the-job training for young women, this could influence marriage patterns, encouraging some women to delay marriage or to combine marriage with strong labor-force attachment. Greater variance in women's patterns of combining marriage and employment could likewise weaken the rationality of employers' use of a statistical discrimination rule against women. Less employer discrimination could also increase educational egalitarianism on the part of the current generation vis-à-vis their sons and daughters. Clearly, labor demand and supply processes are intricately linked in this systemic model of human capital development.

State intervention could also have an effect on the human capital development system by weakening parental reliance on children in old age through increased state participation in pension systems. If the hypotheses in this paper are correct, a decline in parental expectations of financial reliance on children is one element in equalizing educational aspirations for sons and daughters. A host of additional factors besides 
state intervention could also bring about changes in the structure of the human capital development system. For instance, certain types of technological change might render firm-specific training less efficient or necessary, making job-relevant training more available in training institutions across the life cycle and increasing women's degree of control over their own human capital development.

The model I have sketched involves the most basic of society's institutions-institutions in which individuals in all industrial societies have experience. Moreover, the institutions of family, education, and work are often the focal points of separate theories of gender stratification rather than being united into one theory. The present theoretical framework offers a tool for understanding the ways that gender stratification is reproduced not just in the United States and Japan but in other contexts and across other units of analysis as well. Three possible extensions may be mentioned.

First, national comparisons could be extended to include other Asian societies, such as Taiwan, where family and educational patterns resemble Japan's but where the structure of the labor market tends toward small, family-run businesses (Hamilton and Biggart 1986), or to northern European nations, which have greater state involvement in welfare policies that reduce the necessity of having many intergenerational exchanges. In short, a number of national cases could be chosen for comparison on the basis of their variation on the dimensions of their human capital development system. In this manner, the predictions of the theory about the strength of gender stratification patterns under different systems of human capital could be tested on the national level.

Second, the concept of a human capital development system that links family, education, and work organizations could be used to analyze both the differential economic success of various ethnic groups in the United States and varying degrees of gender stratification within such groups. For example, if the assertions in this article about sponsored mobility are correct, one could expect that strong patterns of sponsorship within Asian-American groups would economically benefit those groups overall but would at the same time maintain patterns of gender stratification that are stronger than in ethnic groups that exhibit a different set of relations among family, school, and workplace. In effect, different ethnic groups could be using different systems of human capital development that produce different economic outcomes for the group as a whole and varying degrees of gender stratification within the groups.

Finally, other institutions or social actors not dealt with here-such as labor unions or the state-may be important in producing genderstratification patterns in particular occupations, and the role of these actors could be examined within the framework of human capital devel- 
opment. For instance, it is widely recognized that admission to apprenticeship-training programs (one way of developing human capital) often requires the sponsorship of a union member and thus perpetuates male domination in some jobs (Roos and Reskin 1984). An examination of selected occupations with an eye to how human capital is developed in those occupations may provide important information on the mechanisms by which sex segregation is maintained. ${ }^{27}$ In such a task, the occupation itself serves as the unit of analysis and the interactions among the family as the supplier of labor, the institutions responsible for occupational training, and the structure of the workplace could be examined.

Further work also should address the role of norms more thoroughly. Here, I introduced normative structures as factors exogenous to a human capital development system. The role of each of the hypothesized normative structures was then elucidated in terms of its effect on the decisions made by the key actors in human capital development and the consequent outcome regarding gender stratification in the economy. It is clear that normative and social-institutional structures are not independent, and questions about their interaction as well as their relative roles in initiating social change remain central to sociological theorizing in gender stratification as well as in many other areas.

\section{REFERENCES}

Arrow, Kenneth. 1973. "The Theory of Discrimination." Pp. 3-33 in Discrimination in Labor Markets, edited by O. Ashenfelter and A. Rees. Princeton, N.J.: Princeton University Press.

- 1976. "Economic Dimensions of Occupational Segregation: Comment I." Signs 1:233-37.

Atsumi, Reiko. 1979. "Tsukiai-Obligatory Personal Relationships of Japanese White-Collar Company Employees." Human Organization 38:63-70.

Becker, Gary. (1957) 1971. The Economics of Discrimination. Chicago: University of Chicago Press. search.

. (1964) 1975. Human Capital. New York: National Bureau of Economic Re-

. 1981. A Treatise on the Family. Cambridge, Mass.: Harvard University Press.

Becker, Gary, and Nigel Tomes. 1976. "Child Endowments and the Quantity and Quality of Children." Journal of Political Economy 84:S143-S162.

Beller, Andrea. 1984. "Trends in Occupational Segregation by Sex and Race, 19601981." Pp. 11-26 in Sex Segregation in the Workplace, edited by Barbara F. Reskin. Washington, D.C.: National Academy Press.

Ben-Porath, Yoram. 1980. "The F-Connection: Families, Friends, and Firms and the Organization of Exchange." Population and Development Review 6:1-30.

Bielby, William T., and James N. Baron. 1986. "Men and Women at Work: Sex

${ }^{27}$ A current project headed by Barbara Reskin and Patricia Roos promises to provide some analysis of such issues. 
Segregation and Statistical Discrimination." American Journal of Sociology 91: 759-99.

Blaug, Mark. 1976. "The Empirical Status of Human Capital Theory: A Slightly Jaundiced Survey." Journal of Economic Literature 14:829-55.

Blood, Robert O. 1967. Love Match and Arranged Marriage. New York: Free Press.

Brinton, Mary. 1983. "Principles of Gender Stratification." Seattle: University of Washington, Department of Sociology.

- 1986a. "Determinants of Gender Differences in Initial Employment and Starting Wages in Urban Japan." Paper presented at the annual meeting of the Population Association of America, San Francisco.

. 1986b. "Women and the Economic Miracle: The Maintenance of Gender Differences in Education and Employment in Contemporary Japan." Ph.D. dissertation. University of Washington, Department of Sociology.

Bureau of the Census. 1980. U.S. Census of Population. U.S. Department of Commerce: Bureau of the Census.

Caldwell, John. 1976. "Toward a Restatement of Demographic Transition Theory." Population and Development Review 2:321-66.

Cole, Robert. 1979. Work, Mobility, and Participation. Berkeley and Los Angeles: University of California Press.

Coleman, James S. 1986. "Social Theory, Social Research, and a Theory of Action." American Journal of Sociology 91:1309-35.

Coleman, Samuel. 1983. Family Planning in Japanese Society. Princeton, N.J.: Princeton University Press.

Collins, Randall. 1986. "Is 1980s Sociology in the Doldrums?" American Journal of Sociology 91:1336-55.

Crawcour, Sydney. 1978. "The Japanese Employment System." Journal of Japanese Studies 4:225-45.

Cummings, William K. 1980. Education and Equality in Japan. Princeton, N.J.: Princeton University Press.

Curtis, Richard F. 1986. "Household and Family in Theory on Inequality." American Sociological Review 51:168-83.

England, Paula. 1981. "Assessing Trends in Occupational Sex Segregation, 19001976." Pp. 273-95 in Sociological Perspectives on Labor Markets, edited by Ivar Berg. New York: Academic Press.

- 1983. "Socioeconomic Explanations of Job Segregation." Pp. 28-46 in Comparable Worth and Wage Discrimination: Technical Possibilities and Political Realities, edited by H. Remick. Philadelphia: Temple University Press.

England, Paula, and George Farkas. 1986. Households, Employment, and Gender. New York: Aldine.

Fruin, W. Mark. 1978. "The Japanese Company Controversy." Journal of Japanese Studies 4:267-300.

Granovetter, Mark. 1981. "Toward a Sociological Theory of Income Differences." Pp. 11-47 in Sociological Perspectives on Labor Markets, edited by Ivar Berg. New York: Academic Press.

- 1985. "Economic Action and Social Structure: The Problem of Embeddedness." American Journal of Sociology 91:481-510.

Greenhalgh, Susan. 1985. "Sexual Stratification: The Other Side of "Growth with Equity' in East Asia." Population and Development Review 11:265-314.

Grusky, David B., and Robert Hauser. 1984. "Comparative Social Mobility Revisited: Models of Convergence and Divergence in 16 Countries." American Sociological Review 49:19-38.

Hamaguchi, Esyun. 1985. "A Contextual Model of the Japanese: Toward a Methodological Innovation in Japan Studies." Journal of Japanese Studies 11:289-321.

Hamilton, Gary G., and Nicole Woolsey Biggart. 1988. "Market, Culture, and Au- 
thority: A Comparative Analysis of Management and Organization in the Far East." American Journal of Sociology 94:S52-S94.

Hashimoto, Masanori, and John Raisian. 1985. "Employment Tenure and Earnings Profiles in Japan and the United States." American Economic Review 75:721-35.

Hill, Martha S. 1978. "Self-Imposed Limitations on Work Schedule and Job Location." Pp. 151-93 in Five Thousand American Families: Patterns of Economic Progress, vol. 6. Edited by Greg Duncan and James Morgan. Ann Arbor: University of Michigan, Institute for Social Research.

Hino Municipal Office. 1985. Hino-shi fujin ni kansuru ishiki chosa [Hino city opinion survey concerning women]. Hino, Japan: Hino Municipal Office.

Hogan, Dennis P., and Takashi Mochizuki. 1985. "Demographic Transitions and the Life Course: Lessons from Japanese and American Comparisons." Paper presented at the annual meeting of the American Sociological Association, Washington, D.C.

Koike, Kazuo. 1983. "Workers in Small Firms and Women in Industry." Pp. 89-115 in Contemporary Industrial Relations in Japan, edited by Taishiro Shirai. Madison: University of Wisconsin Press.

Kumon, Shumpei. 1982. "Some Principles Governing the Thought and Behavior of Japanists (Contextualists)." Journal of Japanese Studies 8:5-28.

Lebra, Takie Sugiyama. 1981. "Japanese Women in Male Dominant Careers: Cultural Barriers and Accommodations for Sex-Role Transcendence." Ethnology 20: 291-306.

Maccoby, Eleanor G., and Carol N. Jacklin. 1974. The Psychology of Sex Differences. Stanford, Calif.: Stanford University Press.

McLaughlin, Steven D., and Mary C. Brinton. 1987. "The Changing Life Course of Women: A United States-Japan Comparison." Paper presented at the annual meeting of the American Sociological Association.

Marini, Margaret Mooney. 1978. "Sex Differences in the Determination of Adolescent Aspirations: A Review of Research." Sex Roles 4:723-53.

. 1984. "Age and Sequencing Norms in the Transition to Adulthood." Social Forces 63:229-44.

Marini, Margaret Mooney, and Mary C. Brinton. 1984. "Sex Stereotyping in Occupational Socialization." Pp. 192-232 in Sex Segregation in the Workplace, edited by Barbara F. Reskin. Washington, D.C.: National Academy Press.

Martin, Linda G. 1987. "The Aging of Asia." Paper presented at the annual meeting of the Population Association of America.

Mincer, Jacob. 1962. "Labor Force Participation of Married Women: A Study of Labor Supply." Pp. 63-105 in Aspects of Labor Economics, National Bureau of Economic Research. Princeton, N.J.: Princeton University Press.

- 1974. Schooling, Experience, and Earnings. New York: National Bureau of Economic Research.

Mincer, Jacob, and Solomon Polachek. 1974. "Family Investments in Human Capital: Earnings of Women." Journal of Political Economy 82:S76-S108.

Ministry of Education, Japan. 1985a. Jido, Seito no Gakkagai Gakushu Katsudo ni Kansuru Jittai Chosa [Survey on students' extracurricular study activities]. Tokyo: Ministry of Education.

. 1985b. Gakko Kihon Chosa Hokoku [Basic school statistics]. Tokyo: Ministry of Education.

Ministry of Labor, Japan. 1981. Joshi rodosha no koyo kanri ni kansuru chosa [Survey of employment administration of female employees]. Tokyo: Women's and Minors' Bureau, Ministry of Labor.

. 1985. Joshi rodosha no koyo kanri ni kansuru chosa [Survey of employment administration of female employees]. Tokyo: Women's Bureau, Ministry of Labor.

Morgan, S. Philip, and Kiyosi Hirosima. 1983. "The Persistence of Extended Family 
Residence in Japan: Anachronism or Alternative Strategy?" American Sociological Review 48:269-81.

Morgan, S. Philip, Ronald Rindfuss, and Allan Parnell. 1984. "Modern Fertility Patterns: Contrasts between the United States and Japan." Population and Development Review 10:19-40.

Murakami, Yasusuke. 1984. "Ie Society as a Pattern of Civilization." Journal of Japanese Studies 10:281-363.

Murakami, Yasusuke, Shumpei Kumon, and Seizaburo Sato. 1979. Bunmei to shite no Ie Shakai [Ie society as a civilization]. Tokyo: Chuokoron.

Nagashima, Nobuhiro. 1973. "A Reversed World: Or Is It?" Pp. 92-111 in Modes of Thought: Essays on Thinking in Western and Non-Western Societies, edited by Robin Horton and Ruth Finnegan. London: Faber \& Faber.

Nakamura, Hajime. 1968. "Consciousness of the Individual and the Universal among the Japanese." Pp. 141-60 in The Status of the Individual in East and West, edited by Charles A. Moore. Honolulu: University of Hawaii Press.

Nakane, Chie. 1970. Japanese Society. Berkeley: University of California Press.

Nihon Recruit Center. 1983. Daigakusei (danshi, joshi) no shushoku doki chosa [Jobseeking behavior of male and female university graduates]. Tokyo: Nihon Recruit Center.

- 1984. Joshi gakusei wa nani o kangaete iru ka [What do women students think?]. Tokyo: Nihon Recruit Center.

. 1985. Shinyu shain wa nani o kangaete iru ka [What do new employees think?]. Tokyo: Nihon Recruit Center.

Office of the Prime Minister, Japan. 1973. Sekai seinen ishiki chosa hokokusho [Report on the world youth attitude survey]. Tokyo: Youth Policy Office.

. 1979. Fujin ni kansuru ishiki chosa [Opinion survey concerning women]. Tokyo: Office of the Prime Minister.

Prime Minister.

- 1982a. Fujin mondai ni kansuru kokusai hikaku [Comparative survey on women's problems]. Tokyo: Office of the Prime Minister.

- 1982b. Kyoiku ni kansuru yoron chosa [Opinion survey on education]. Tokyo: Office of the Prime Minister.

- 1983. Kakei Chosa Nenpo [Annual report on the family income and expenditure survey]. Tokyo: Statistics Bureau, Management and Coordination Agency.

Ohashi, Y. 1981. "Rodo shijo no nichibei hikaku" [A comparison of the labor market in Japan and the United States]. Gendai Keizai, vol. 43. [In Japanese]

Phelps, E. S. 1972. "The Statistical Theory of Racism and Sexism." American Economic Review 62:659-61.

Polachek, Solomon. 1976. "Occupational Segregation: An Alternative Hypothesis." Journal of Contemporary Business 5:1-12.

1979. "Occupational Segregation among Women: Theory, Evidence, and a Prognosis." Pp. 137-57 in Women in the Labor Market, edited by Cynthia B. Lloyd, Emily S. Andrews, and Curtis L. Gilroy. New York: Columbia University Press.

- 1981. "Occupational Self-Selection: A Human Capital Approach to Sex Differences in Occupational Structure." Review of Economics and Statistics 63:60-69.

Rohlen, Thomas P. 1977. "Is Japanese Education Becoming Less Egalitarian? Notes on High School Stratification and Reform." Journal of Japanese Studies 3:37-70.

. 1983. Japan's High Schools. Berkeley and Los Angeles: University of California Press.

Roos, Patricia A. 1985. Gender and Work: A Comparative Analysis of Industrial Societies. Albany: State University of New York Press. 
Roos, Patricia A., and Barbara F. Reskin. 1984. "Institutional Factors Contributing to Sex Segregation in the Workplace." Pp. 192-232 in Sex Segregation in the Workplace, edited by Barbara F. Reskin. Washington, D.C.: National Academy Press.

Rosenfeld, Rachel. 1984. "Job Changing and Occupational Sex Segregation: Sex and Race Comparisons." Pp. 56-86 in Sex Segregation in the Workplace, edited by Barbara F. Reskin. Washington, D.C.: National Academy Press.

Rosenzweig, Mark R. 1982. "Wage Structure and Sex-Based Wage Inequality: The Family as Intermediary." Population and Development Review, suppl. to 8:192206.

Seiyama, K., and T. Noguchi. 1984. "The Effects of Investment in Extra-School Schooling on Advancement to High School." Research in Sociology of Education 38:113-126. [In Japanese]

Shimada, Haruo. 1981. Earnings Structure and Human Investment: A Comparison between the United States and Japan. Tokyo: Kogadusha Limited.

- 1983. "Japanese Industrial Relations-A New General Model? A Survey of the English-Language Literature." Pp. 3-27 in Contemporary Industrial Relations in Japan, edited by Taishiro Shirai. Madison: University of Wisconsin Press.

Smith, James P., and Finis Welch. 1984. "Affirmative Action and Labor Markets." Journal of Labor Economics 2:269-301.

Spence, Michael. 1973. "Job Market Signaling." Quarterly Journal of Economics $87: 355-74$.

Stockard, Jean, and Miriam M. Johnson. 1980. Sex Roles: Sex Inequality and Sex Role Development. Englewood Cliffs, N.J.: Prentice-Hall.

Tominaga, Kenichi. 1979. "Shakai kaiso to shakai ido no susei bunseki" [A trend analysis of social class and social mobility]. Pp. 33-87 in Nihon no Kaiso Kozo [The structure of Japanese social stratification]. Tokyo: Tokyo University Press.

Treiman, Donald J., and Heidi T. Hartmann. 1981. Women, Work, and Wages: Equal Pay for Jobs of Equal Value. Washington, D.C.: National Academy Press.

Turner, Ralph. 1960. "Modes of Social Ascent through Education: Sponsored and Contest Mobility." American Sociological Review 25:121-39.

United Nations 1982a. Demographic Yearbook. New York: United Nations.

. 1982b. Statistical Yearbook. New York: United Nations.

Vogel, Ezra. 1967. Japan's New Middle Class. Berkeley: University of California Press.

Willis, Robert. 1982. "The Direction of Intergenerational Transfers and Demographic Transition: The Caldwell Hypothesis Reexamined." Population and Development Review, suppl. to 8:207-234.

Yamamura, Kozo, and Susan B. Hanley. 1975. "Ichi hime, ni Taro: Educational Aspirations and the Decline in Fertility in Postwar Japan." Journal of Japanese Studies 2:83-125.

Yakawa, Hideki. 1967. "Modern Trends of Western Civilization and Cultural Peculiarities in Japan." Pp. 52-60 in The Japanese Mind: Essentials of Japanese Philosophy and Culture, edited by Charles A. Moore. Honolulu: East-West Center Press and University of Hawaii Press. 